\title{
Возраст золотого оруденения месторождения Унгличикан (Дальний Восток России): результаты 40Ar/39Ar геохронологических исследований
}

Кадашникова А. Ю., Сорокин А. А., Пономарчук А. В., Травин А. В., Пономарчук В. А.

\begin{abstract}
Аннотация
В результате проведенных изотопно-геохронологических исследований установлено, что возраст рудных метасоматитов золоторудного месторождения Унгличикан может быть оценен в 140-136 млн лет. Данные о проявлении магматизма в пределах рассматриваемого региона с таким возрастом отсутствуют, что делает невозможным связать рудную минерализацию месторождения Унгличикан с магматическими процессами. Возраст термального события, наложенного на вмещающие породы златоустовской свиты вне рудной зоны, составляет $140 \pm 2$ млн лет. Таким образом, последний этап метаморфизма и деформаций регионального характера, с одной стороны, и формирование рудных метасоматитов, с другой стороны, имеют один и тот же возраст. По мнению авторов, значимую роль в мобилизации, перераспределении рудного вещества и формировании месторождения Унгличикан сыграли процессы деформации орогена, сопровождаемые гидротермальной деятельностью.
\end{abstract}

\section{Ключевые слова:}

Монголо-Охотский складчатый пояс, золоторудное месторождение Унгличикан, золото, 40Ar/39Ar геохронология 
УДК 553.41:553.065

\title{
ВОЗРАСТ ЗОЛОТОГО ОРУДЕНЕНИЯ МЕСТОРОЖДЕНИЯ УНГЛИЧИКАН (ДАЛЬНИЙ ВОСТОК РОССИИ): РЕЗУЛЬТАТЫ ${ }^{40} \mathrm{AR} /{ }^{39} \mathrm{AR}$ ГЕОХРОНОЛОГИЧЕСКИХ ИССЛЕДОВАНИЙ
}

\author{
А.Ю. Кадашникова ${ }^{1}$, А.А. Сорокин ${ }^{1}$, А.В. Пономарчук ${ }^{2}$, А.В. Травин ${ }^{2}$, В.А. Пономарчук ${ }^{2}$ \\ ${ }^{1}$ Институт геологии и природопользования ДВО РАН, 675000, г. Благовещенск, пер. \\ Релочный, д.1, Россия \\ ${ }^{2}$ Институт геологии и минералогии СО РАН, 630090, Новосибирск, \\ пр. Ак. Коптюга, д. 3, Россия
}

\begin{abstract}
В результате проведенных изотопно-геохронологических исследований установлено, что возраст рудных метасоматитов золоторудного месторождения Унгличикан может быть оценен в 140-136 млн лет. Данные о проявлении магматизма в пределах рассматриваемого региона с таким возрастом отсутствуют, что делает невозможным связать рудную минерализацию месторождения Унгличикан с магматическими процессами. Возраст термального события, наложенного на вмещающие породы златоустовской свиты вне рудной зоны, составляет $140 \pm 2$ млн лет. Таким образом, последний этап метаморфизма и деформаций регионального характера, с одной стороны, и формирование рудных метасоматитов, с другой стороны, имеют один и тот же возраст. По мнению авторов, значимую роль в мобилизации, перераспределении рудного вещества и формировании месторождения Унгличикан сыграли процессы деформации орогена, сопровождаемые гидротермальной деятельностью.
\end{abstract}

Ключевые слова: Монголо-Охотский складчатый пояс, золоторудное месторождение Унгличикан, золото, ${ }^{40} \mathrm{Ar}{ }^{\beta 9} \mathrm{Ar}$ геохронология.

Keywords: Mongol-Okhotsk fold belt, Unglichikan gold deposit, gold, ${ }^{40} \mathrm{Ar} /{ }^{\beta 9} \mathrm{Ar}$ geochronology.

\section{ВВЕДЕНИЕ}

Получение надежных геохронологических данных о возрасте гидротермальных рудных процессов представляет собой сложную и важную задачу, являющуюся составной частью проблемы взаимосвязи геодинамики, магматизма и формирования месторождений полезных ископаемых. Монголо-Охотский складчатый пояс, являющийся одной из главнейших структур Центральной и Восточной Азии, может служить весьма благоприятным объектом для исследований в этом направлении. Этот пояс протягивается в виде узкой (до 300 км) прерывистой полосы на 3000 км от Удской губы Охотского моря до Центральной Монголии (рис. 1). В современном структурном плане он представляет собой сложный коллаж палеозойских и раннемезозойских комплексов, зажатых между крупными континентальными блоками Восточной Азии - Северо-Азиатским кратоном и Амурским супертеррейном, и часто описывается как шовная зона или сутура [Натальин, 1991; Парфенов и др., 1999; Геодинамика ..., 2006].

Возраст окончательного формирования Монголо-Охотского складчатого пояса и закрытия палеоокеана является предметом дискуссий. Ряд исследователей [Ларин и др., 2006, 2014; Сальникова и др., 2006; Донская и др., 2012; Donskaya et al., 2013; Котов и др., 2013, 2014; и др.] на основе анализа мезозойского магматизма и метаморфизма к югу и 
северу от складчатого пояса полагает, что пик коллизионных процессов приходится на ранний мел. Раннемеловой возраст закрытия Монголо-Охотского океана поддерживается также палеомагнитными данными [Zhao et al., 1994; Kravchinsky et al., 2002; Metelkin et al., 2004, 2007, 2010; Ren et al., 2016]. Однако возраст наиболее молодых морских отложений Монголо-Охотского пояса ограничивается ранней юрой [Парфенов и др., 1999; Sorokin et al., 2020], а юрские осадочные бассейны, обрамляющие пояс с севера и юга, имеют орогенное происхождение [Не et al., 2005; Смирнова и др., 2017; Заика и др., 2020] и содержат уголь [Сережников, Волкова, 2005]. Все это указывает на то, что возраст орогенеза в восточной части Монголо-Охотского пояса приходится на рубеж ранней и поздней юры [Sorokin et al., 2020]. Аналогичный вывод был сделан на основе исследований осадочных бассейнов, прилегающих к западной части пояса [Demonterova et al., 2017].

Сложная длительная история формирования Монголо-Охотского орогенного пояса сопровождалась становлением разновозрастных магматических поясов и рудных месторождений как в пределах пояса, так и его континентального обрамления. При этом исследователями уже давно подмечена пространственная сопряженность ареалов распространения рудных объектов и конфигурации Монголо-Охотского пояса. Существует несколько гипотез образования орогенных золоторудных месторождений (см. обзор в [Goldfarb, Groves, 2015; Горячев, 2019; Савчук, Волков, 2019; Groves et al., 2020]). Традиционно генезис орогенных золоторудных месторождений рассматривался с позиций магматогенно-гидротермальной модели, в которой ведущая роль отводится магме разного состава [Горячев 2014; Савчук, Волков, 2019; и др.]. Позже были предложены метеорная и осадочно-гидротермальная гипотезы. Также предложены метаморфогенная или метамофогенно-деформационная модель [Goldfarb, Groves, 2015; Савчук, Волков 2019; Groves et al., 2020; и др.]. В тоже время протестировать ту или иную модель формирования возможно только при наличии надежных геохронологических данных. Вплоть до недавнего времени, изотопно-геохронологическая изученность большинства рудных объектов в пределах Монголо-Охотского пояса оставалась слабой, что существенно затрудняло корреляцию тектонических, магматических и рудообразующих процессов. В последние годы этот пробел был существенно восполнен. С использованием современных изотопных методов были получены датировки для ряда месторождений и рудопроявлений золота и комплексных руд, расположенных в пределах Монголо-Охотского орогенного пояса и его континентального обрамления на территории Монголии, Восточного Забайкалья и Приамурья [Булгатов, Гордиенко, 1999; Сотников и др., 2007а, 2007б; Сорокин и др., 2014а, 2014б, Бучко и др., 2012, 2014, 2017; Берзина и др., 2013; Кадашникова и др., 2019а, 2019б, 2019в; и др.]. Однако геохронологические данные для рудных объектов, расположенных непосредственно в складчатой структуре пояса, имеются в весьма ограниченном объеме.

В данной работе приведены результаты исследования гидротермальных рудных метасоматитов золоторудного месторождения Унгличикан, относящегося к золотокварцевой малосульфидной формации (золото-шеелитовый минеральный тип) [Васильев и др., 2000] или орогенному типу [Горячев, 2019; Groves et al., 2020].

\section{ГЕОЛОГИЧЕСКАЯ ПОЗИЦИЯ МЕСТОРОЖДЕНИЯ И ОБЪЕКТЬ ИССЛЕДОВАНИЙ}

Месторождение Унгличикан находится в восточной части Монголо-Охотского 
складчатого пояса (рис. 1), наряду с такими золоторудными месторождениями как Токур, Сагур, Маломыр, Албын, Ворошиловское и др. Оно входит в состав Харгинского рудного поля и расположено в пределах Селемджино-Кербинской структурной зоны [Агафоненко и др., 2002] или одноименного террейна аккреционного клина [Сорокин и др., 2003].

Месторождение расположено в поле развития слабометаморфизованных пород верхнекаменноугольной (?) златоустовской свиты, прорванных дайками диоритовых порфиритов и андезитов ранне-позднемелового селитканского комплекса [Агафоненко и др., 2002]. Златоустовская свита (по [Агафоненко и др., 2002, 2015; Забродин и др., 2007]) сложена кварц-серицитовыми, часто углеродсодержащими сланцами, эпидот-актинолитальбитовыми, кварц-эпидот-хлоритовыми, хлорит-актинолит-кварц-альбитовыми, мусковит-кварц-альбитовыми сланцами, метапесчаниками, филлитизированными глинистыми сланцами, метабазальтами, мраморизованными известняками. Характерным ее признаком является наличие углеродсодержащих сланцев. Общая мощность свиты превышает 1600 м. Представления о ее позднекаменноугольном возрасте основываются на споро-пыльцевом комплексе, характерном для визейского-московского веков [Забродин и др., 2007].

Оруденение приурочено к зоне Унгличиканского разлома (рис. 1) шириной более 400 м северо-восточного простирания с падением на север под углами 65-85² [Агафоненко и др., 2015]. Месторождение представляет собой серию сопряженных с этим разломом субпараллельных зон брекчированных гидротермально измененных пород, несущих золотое (с шеелитом) оруденение, мощностью от 0.1 до 2 - 10 м и протяженностью около 2 KM.

На месторождении всего установлено более 30 рудных зон [Агафоненко и др., 2015; Васильев и др., 2000], из которых наиболее изучены зоны Хабаровская, Северная, Южная, Шеелитовая, Милонитовая, Центральная, Брекчиевая, Леоновская (рис. 1). По морфологическому типу они относятся к минерализованным тектоническим зонам, выполненным милонитами и катаклазитами, замещенными рудно-метасоматическими образованиями. Рудные зоны имеют лентовидную форму. Протяженность их от 380 до 2700 м, мощность 0.15-7.8 м (средняя - 2.4 м). Падение на север чаще под углами 65-75 . По падению прослежены на 60-300 м. [Агафоненко и др., 2002; Васильев и др., 2000]. Согласно результатам минералогических исследований [Эйриш, 2002; Агафоненко и др., 2015; Васильев и др., 2000] рудные тела представляют собой золотосодержащие брекчиевидные кварц-золото-сульфидные, обогащенные углеродом кварц-карбонатальбитовые, адуляр-кварц-серицит-сульфидные метасоматиты. Околорудные изменения выражены в окварцевании, карбонатизации, альбитизации, сульфидизации, адуляризации. Мощность зон изменений достигает 70-100 м [Агафоненко и др., 2015]. Рудные минералы представлены шеелитом, арсенопиритом, пиритом, антимонитом, сфалеритом, галенитом, золотом [Эйриш, 2002]. Среди сульфидов, содержание которых составляет 3-5\%, преобладают арсенопирит, пирит, сфалерит, халькопирит, галенит, антимонит [Агафоненко и др., 2015]. Текстура руд полосчатая, брекчиевая, реже отмечаются прожилковые и вкрапленные руды [Мельников, Степанов 2014]. Форма золотин преимущественно губчатая, дендритовидная, каплевидная, пластинчатая, размер от 0.005 до 0.5 мм. Отмечаются сростки золота с арсенопиритом и галенитом, иногда в лимонитовой рубашке; проба золота - 800-850.

Распределение оруденения по простиранию рудных зон крайне неравномерное. Наиболее золотоносны рудные брекчии и кварц-альбитовые метасоматиты с адуляром 
[Эйриш, 2002]. Участки промышленных концентраций золота чередуются с бедными. Протяженность первых не превышает 400 м [Агафоненко и др., 2015]. Содержания золота варьирует от 0.1 до 1094 г/т [Эйриш, 2002; Мельников, Степанов, 2014]. Все рудные тела не имеют геологических границ и определяются только по данным опробования.

Для установления возраста проявления гидротермальных процессов нами были проведены геохронологические $\left({ }^{40} \mathrm{Ar} /{ }^{39} \mathrm{Ar}\right.$ метод) исследования адуляр-кварц-серицитсульфидных рудных метасоматитов Хабаровской зоны, углеродсодержащих кварцполевошпат-слюдистых сланцев златоустовской свиты, вмещающих оруденение, а также

Рис. 2

Табл. 1 пострудной дайки андезитов селитканского комплекса. Места отбора образцов показаны на рисунках 1 и 2, а содержания золота в анализировавшихся образцах приведены в таблице 1.

Хабаровская рудная зона протяженностью 1.2 км находится в северо-западной части месторождения Унгличикан. По [Эйриш, 2002] на штольневом горизонте 775 м рудная зона образована сетью сложноветвящихся прожилков друзовидного кварца, рассекающих дробленые участки милонитизированных сланцев, круто падающих в северных румбах. Кварц содержит редкую (1-5\%) вкрапленность сульфидов, среди которых доминирует пирит. Шеелит встречается в виде прожилков (до 1 см), рассеянной вкрапленности и гнездообразных скоплений. Содержание вольфрама в руде 0.05-0.9\%, в кварцевых прожилках - 0.1-3\%. В пределах Хабаровской зоны оконтурено несколько рудных тел, с падением на север-северо-запад под углами 50-90. Одним из самых крупных на месторождении является рудное тело Хабаровское-1 длиной 830 м, средней мощностью 3-5 м и средним содержанием 18 г/т.

\section{АНАЛИТИЧЕСКИЕ МЕТОДИКИ}

${ }^{40} \mathrm{Ar} /{ }^{39} \mathrm{Ar}$ изотопно-геохронологические исследования выполнены в Институте геологии и минералогии СО РАН (г. Новосибирск) методом ступенчатого прогрева по методике, опубликованной в работах [Пономарчук и др., 1998; Травин и др., 2009].

Изотопное датирование проведено по мономинеральным фракциям, отбор которых производился вручную под бинокулярной лупой из фракции 0.25-0.15 мм измельченного образца. Навески образцов, совместно с мусковитом МСА-11, используемым в качестве монитора, заворачивались в алюминиевую фольгу, помещались в кварцевую ампулу и после откачки из нее воздуха запаивались. Мусковит МСА-11, подготовленный в ВИМС в 1988 году как стандартный K/Ar-образец, был аттестован в качестве ${ }^{40} \mathrm{Ar} /{ }^{39} \mathrm{Ar}$-монитора с помощью международных стандартных образцов мусковита Bern 4m, биотита LP-6 [Baksi et al., 1996]. В качестве интегрального возраста мусковита МСА-11 принято среднее результатов калибровки, составившее $311.0 \pm 1.5$ млн лет. Облучение проб было проведено в кадмированном канале научного реактора ВBР-К типа в Научно-исследовательском институте ядерной физики (Томск). Градиент нейтронного потока за период облучения не превышал $0.5 \%$ в размере образца. Холостой опыт по определению ${ }^{40} \mathrm{Ar}$ (10 мин при $1200^{\circ} \mathrm{C}$ ) не превышал $5 \times 10^{-10}$ нсм $^{3}$. Очистку аргона производили с помощью Ti- и ZrAlSAES-геттеров. Изотопный состав аргона измерялся на масс-спектрометре Noble gas 5400 фирмы "Микромасс" (Англия) в Институте геологии и минералогии СО РАН (г. Новосибирск). Для коррекции на изотопы ${ }^{36,37,40} \mathrm{Ar}$, полученные при облучении $\mathrm{Ca}, \mathrm{Cl}, \mathrm{K}$, использованы следующие коэффициенты: $\left({ }^{39} \mathrm{Ar} /{ }^{37} \mathrm{Ar}\right)_{\mathrm{Ca}}=0.00073 \pm 0.000026,\left({ }^{36} \mathrm{Ar} /{ }^{37} \mathrm{Ar}\right)_{\mathrm{Ca}}=$ $0.00032 \pm 0.000021,\left({ }^{40} \mathrm{Ar} /{ }^{39} \mathrm{Ar}\right)_{\mathrm{K}}=0.0641 \pm 0.0001$. Особое внимание уделялось контролю фактора изотопной дискриминации с помощью измерения порции очищенного 
атмосферного аргона. Среднее значение отношения ${ }^{40} \mathrm{Ar} /{ }^{36} \mathrm{Ar}$ на период измерений составило 296.5 \pm 0.5. Величины температур ступенчатого прогрева выбирались согласно [Berger, York, 1981]. При обработке результатов учитывались рекомендации, опубликованные в работах [Fleck et al, 1977; Gustafson et al, 2001].

Определение содержаний золота в породах выполнено атомно-абсорбционным методом с использованием стандартных методик кислотного разложения на спектрометре Solaar M6 + Zeeman Furnace (Thermo electron corporation, USA) с электротермической атомизацией в Институте геологии и природопользования ДВО РАН (г. Благовещенск, аналитики Н.А. Бородина, Е.Е. Зайцева, Н.Н. Козлова).

Табл. 2

Рис. 3

\section{РЕЗУЛЬТАТЫ ГЕОХРОНОЛОГИЧЕСКИХ ИССЛЕДОВАНИЙ}

Результаты проведенных исследований приведены в таблице 2, а также на рисунке 3 и сводятся к следующему (возраст приведен с погрешностью $\pm 2 \sigma$ ):

1) возраст адуляра из адуляр-кварц-серицит-сульфидного рудного метасоматита (обр. АК-70) при расчете по плато (80\% выделенного ${ }^{39} \mathrm{Ar}$ ) составляет $140 \pm 3$ млн лет (табл. 2, рис. 3а);

2) возраст адуляра из адуляр-кварц-серицит-сульфидного рудного метасоматита (обр. AK-71-3) при расчете по плато (77\% выделенного ${ }^{39} \mathrm{Ar}$ ) составляет $136 \pm 2$ млн лет (табл. 2, рис. Зб);

3) возраст серицита из углеродсодержащих кварц-полевошпат-слюдистых сланцев златоустовской свиты (обр. АК-72-1), вмещающих оруденение, при расчете по плато (78\% выделенного ${ }^{39} \mathrm{Ar}$ ) составляет $140 \pm 2$ млн лет (табл. 2, рис. Зв);

4) возраст основной массы пострудной дайки андезитов селитканского комплекса (обр. АК-73) в расчете по плато составляет $98 \pm 4$ млн лет (97\% выделенного $\left.{ }^{39} \mathrm{Ar}\right)$ (табл. 2, рис. Зг).

\section{ОБСУЖДЕНИЕ РЕЗУЛЬТАТОВ}

Выше было отмечено, что рудные тела месторождения Унгличикан представлены преимущественно кварц-золото-сульфидными, кварц-карбонат-альбитовыми, адуляркварц-серицит-сульфидными метасоматитами. Исходя из этого, пригодными для ${ }^{40} \mathrm{Ar} /{ }^{39} \mathrm{Ar}$ геохронологических исследований К-содержащими минералами, и одновременно связанными с процессом гидротермального минералообразования [Эйриш, 2002], являются адуляр и серицит. Для установления возраста этого процесса мы использовали адуляр из адуляр-кварц-серицит-сульфидных рудных метасоматитов (обр. AK-70 и AK-71$3)$.

Также следует принимать во внимание, что границы рудных тел в пределах месторождения устанавливаются только опробованием и не имеют минералогических критериев, что чрезвычайно затрудняет исследование стадийности минералообразования (рудообразования). Для соблюдения максимально возможной в данном случае корректности для геохронологических исследований мы использовали образцы метасоматитов с достаточно высокими концентрациями золота, что позволяет нам отождествлять возраст гидротермальных процессов, с одной стороны, и рудоотложения, с другой. В частности, содержания золота в образце АK-70 составляет 4.51 г/т, в образце AK-71-3 - 17.65 г/т (табл. 1). Таким образом, на основании вышесказанного мы полагаем, что возраст кристаллизации адуляра из адуляр-кварц-серицит-сульфидных рудных метасоматитов отражает возраст гидротермальных рудных процессов. 
Обратившись к результатам геохронологических исследований, отметим, что полученные две датировки для адуляров из рудных метасоматитов месторождения Унгличикан близки между собой в пределах погрешности и составляют $140 \pm 3$ млн лет (обр. AK-70) и $136 \pm 3$ млн лет (обр. АK-71-3) (табл. 2, рис. За,б). Таким образом, возраст гидротермального рудного процесса на месторождении Унгличикан, в первом приближении, может быть оценен интервалом 140-136 млн лет.

Эта оценка оказалась несколько более древней, чем таковые ранее полученные для месторождений Албын 131-130 млн лет [Кадашникова и др., 2019а, 2019б] и Маломыр 134-130 млн лет [Кадашникова и др., 2019в], также расположенных в СелемджиноКербинской структурной зоне восточной части Монголо-Охотского складчатого пояса. В тоже время на аргонограммах рудных метасоматитов указанных месторождений присутствуют ступени с возрастами 136-140 млн лет [Кадашникова и др., 2019а, 2019б, 2019в], что может свидетельствовать о нескольких этапах рудного процесса.

Как показывает практика, геохронологические исследования зачастую позволяют связать рудообразующий процесс с тем или иным магматическим комплексом. Однако в нашем случае это оказалось затруднительным. Так, результаты выполненных исследований и анализ опубликованных данных указывают на то, что геохронологические свидетельства проявления магматизма в пределах рассматриваемого региона с возрастом, близким к возрасту оруденения (140-136 млн лет), отсутствуют. В частности, гранитоиды златоустовского и ингаглинского комплексов имеют позднепалеозойский возраст [Агафоненко и др., 2002; Сорокин и др., 2003; Забродин и др., 2007], а мезозойские вулканические и субвулканические и дайковые породы - не древнее альба [Агафоненко и др., 2002; Забродин и др., 2007].

В этой связи необходимо искать иные геологические причины, обусловившие формирование целой серии месторождений (Албын, Унгличикан, Маломыр и др.) в восточной части Монголо-Охотского складчатого пояса. В вводной части статьи было отмечено, что на основании результатов детальных исследований детритовых цирконов в осадочных толщах Монголо-Охотского пояса и орогенных впадин в его обрамлении установлено, что возраст орогенеза в восточной части Монголо-Охотского пояса приходится на рубеж ранней и поздней юры (см. обзор в [Sorokin et al., 2020]). В этой связи связать формирование месторождения Унгличикан, так же как и Албын и Маломыр, с субдукционными или коллизионными процессами, сопровождавшими закрытие Монголо-Охотского океана, невозможно.

Один из возможных вариантов решения указанной проблемы - связать формирование месторождений в восточной части Монголо-Охотского пояса с сопровождаемыми гидротермальной деятельностью процессами деформации орогена, проявившимися уже после закрытия океанического бассейна. Ранее такая идея была предложена нами для месторождений Маломыр и Албын [Кадашникова и др., 2019а, 2019б, 2019в]. Результаты геохронологических исследований, представленных в настоящей статье, подтверждают возможность такой интерпретации. В частности, для серицита из углеродсодержащих кварц-полевошпат-слюдистых сланцев златоустовской свиты (обр. АК-72-1), вмещающих оруденение на месторождении Унгличикан, получен возраст $140 \pm 3$ млн лет (табл. 2, рис. Зв). Как видим, он полностью соответствует возрасту адуляра (140-136 млн лет) из рудных метасоматитов (обр. АК-70 и АК-71-3). Подчеркнем, что образец AK-72-1 отобран вне рудной зоны для характеристики возраста собственно метаморфических процессов, и он практически не содержит золота (табл. 1). В этой связи 
напрашивается тезис о том, что последний этап метаморфизма (термального прогрева) и деформаций регионального характера (серицит из безрудного сланца златоустовской свиты) и формирование руды (адуляр из рудных метасоматитов) имеют один и тот же возраст. Об определяющей роли тектонических процессов (складкообразовании, сдвигов, надвигов), а также метаморфизма в формировании месторождений восточной части Монголо-Охотского свидетельствуют и структурные исследования [Эйриш, 2002; Агафоненко и др., 2002; Забродин и др., 2007; Лазарев и др., 2012]. В тоже время эта модель требует дальнейшего подтверждения или опровержения.

Но чем могли быть обусловлены тектонические и сопряженные с ними гидротермальные процессы? По нашему мнению, одной из причин их могло стать вращение Сибирского кратона по часовой стрелке, происходившее в раннемеловое время [Баженов, Моссаковский, 1986; Парфенов и др., 2003; Natal’in, Sengor, 2005; Metelkin et al., 2010]. Это привело к деформации не только Монголо-Охотского пояса, но и ДжугджуроСтанового супертеррейна (окраины Сибирского кратона), где возраст последнего этапа регионального метаморфизма оценивается 140-135 млн лет [Сальникова и др., 2006; Котов и др., 2014; Великославинский и др., 2017; Ларин и др., 2018; и др.]. С другой стороны, синсдвиговая конфигурация разломов Монголо-Охотского пояса, специфическая морфология юрских и меловых интрузий южной окраины Сибирского кратона вполне могут указывать на трансформную природу позднеюрско-раннемелового этапа формирования Монголо-Охотского пояса [Ханчук, 2000].

В завершении обратимся к пострудной дайке андезитов селитканского комплекса на месторождении Унгличикан. Согласно полученным данным, возраст этих пород составляет $98 \pm 4$ млн лет (табл. 2, рис. Зг). Ранее были получены датировки для даек андезибазальтов и базальтов бурундинского (?) комплекса на месторождении Маломыр: $104 \pm 1$ млн лет и $105 \pm 1$ млн лет [Кадашникова и др., 2019в]. Эти данные лишний раз подчеркивают, что дайки и субвулканические тела, проявленные в пределах месторождений в восточной части Монголо-Охотского пояса, существенно моложе оруденения.

\section{ВЫВОДЫ}

Полученные в результате проведенных исследований результаты позволяют сформулировать следующие выводы:

1) Возраст гидротермальных рудных процессов, приведших к формированию месторождения Унгличикан, может быть оценен интервалом 140-136 млн лет, а возраст пострудных даек селитканского комплекса - $98 \pm 4$ млн лет.

2) Возраст термального события, наложенного на вмещающие породы златоустовской свиты вне рудной зоны, составляет $140 \pm 2$ млн лет. Таким образом, последний этап метаморфизма и деформаций регионального характера, с одной стороны, и формирование рудных метасоматитов, с другой стороны, имеют один и тот же возраст.

3) Геохронологические свидетельства проявления магматизма в пределах рассматриваемого региона с возрастом 140-136 млн лет отсутствуют, что делает невозможным связать рудную минерализацию месторождения Унгличикан с магматическими процессами.

4) Скорее всего, формирование месторождений в восточной части МонголоОхотского пояса связано с процессами деформации орогена, сопровождаемыми гидротермальной деятельностью. 


\section{БЛАГОДАРНОСТИ}

Авторы выражают благодарность руководству ЗАО ГК “Петропавловск”, ООО "НПГФ "Регис" и А.А. Басенко за помощь в организации полевых работ и сборе материалов, а также сотрудникам лабораторий Института геологии и природопользования ДВО РАН О.Н. Белозеровой, В.В. Глушенковой за подготовку препаратов для геохронологических исследований, Н.А. Бородиной, Е.Е. Зайцевой и Н.Н. Козловой за определение концентраций золота в образцах. Кроме того, авторы искренне признательны доктору геол.-мин. наук А.В. Волкову и анонимному рецензенту за внимательный анализ рукописи, дискуссию и конструктивные замечания.

\section{ИСТОЧНИКИ ФИНАНСИРОВАНИЯ}

Геохронологические исследования выполнены при поддержке Российского научного фонда (проект 18-17-00002).

\section{СПИСОК ЛИТЕРАТУРЫ}

Агафоненко С.Г., Сережников А.Н., Яшнов А.Л. Ненашева С.В., Усов И.О., Асмолова Е.И., Карпеченкова Н.Ю., Милицина Н.С. Государственная геологическая карта Российской Федерации масштаба 1:200 000. Издание второе. Серия Тугурская. Лист N-53-XXVI / Под ред. Махинина А.В. СПб., ВСЕГЕИ, 2002.

Агафоненко С.Г., Усов И.О., Сережников А.Н., Ненашева С.В., Асмолова Е.И., Яшнов А.Л. Государственная геологическая карта Российской Федерации. Масштаб 1:200 000. Издание второе. Серия Тугурская. Лист N-53-XXVI. Златоустовск. Объяснительная записка / Под ред. Махинина А.В. М: МФ ВСЕГЕИ, 2015, 98 с.

Баженов М.Л., Моссаковский А.А. Горизонтальные перемещения Сибирской платформы в триасе, по палеомагнитным и геологическим данным // Геотектоника, 1986, № 1, с. 59-69.

Берзина А.П., Берзина А.Н., Гимон В.О., Крымский Р.Ш., Ларионов А.Н., Николаева И.В., Серов П.А. Шахтаминская Мо-порфировая рудно-магматическая система (Восточное Забайкалье): возраст, источники, генетические особенности // Геология и геофизика, 2013, т. 54, № 6, с. 764-786.

Булгатов А.Н, Гордиенко И.В. Террейны Байкальской горной области и размещение в их пределах месторождений золота // Геология рудных месторождений, 1999, т. 41, № 3, с. 230-240.

Бучко И.В., Бучко Ир.В., Сорокин А.А., Пономарчук В.А., Травин А.В. Закономерности локализации оруденения, возраст и связь с магматизмом сереброполиметаллического месторождения Моготинское (Северо-Становая металлогеническая зона, юго-восточное обрамление Северо-Азиатского кратона) // Геология рудных месторождений, 2014, т. 56, № 2, с. 118-130.

Бучко И.В., Сорокин А.А., Пономарчук А.В., Травин А.В., Пономарчук В.А. ${ }^{40} \mathrm{Ar} /{ }^{39} \mathrm{Ar}$ возраст и связь с магматизмом медно-порфирового с золотом оруденения рудопроявления Елна (северо-восточная часть Аргунского супертеррейна) // Доклады академии наук, 2017, т. 472, № 2, с. 175-179.

Бучко И.В., Сорокин А.А., Пономарчук В.А., Травин А.В., Бучко Ир.В. Возраст и связь с магматизмом золото-серебряного оруденения рудопроявления Десс Северо- 
Становой металлогенической зоны (юго-восточное обрамление Северо-Азиатского кратона) // Тихоокеанская геология, 2012, т. 31, № 2, с. 69-74.

Васильев И.А., Капанин В.П., Ковтонюк Г.П., Мельников В.Д., Лужнов А.П., Данилов А.П., Сорокин А.П. Минерально-сырьевая база Амурской области на рубеже веков. Благовещенск, 2000, 168 с.

Великославинский С.Д., Котов А.Б., Ковач В.П., Толмачева Е.В., Сорокин А.А., Сальникова Е.Б., Ларин А.M., Загорная H.Ю., Wang K.L., Chung S.L., Ярмолюк В.В., Хераскова Т.Н. Возраст и тектоническое положение метаморфического Станового комплекса (восточная часть Центрально-Азиатского складчатого пояса) // Геотектоника, 2017, № 4, с. 3-16.

Геодинамика, магматизм и металлогения востока России. Кн. 1 / Ред. Ханчук А.И. Владивосток: Дальнаука, 2006, 572 с.

Горячев Н.А. Благороднометалльный рудогенез и мантийно-коровое взаимодействие // Геология и геофизика, 2014, т. 55, № 2, с. 323-332.

Горячев Н.А. Месторождения золота в истории Земли // Геология рудных месторождений, 2019, т. 61, № 6, с. 3-18.

Донская Т.В., Гладкочуб Д.П., Мазукабзов А.М., де Ваэле Б., Пресняков С.Л. Позднетриасовая Катаевская вулканоплутоническая ассоциация Западного Забайкалья фрагмент активной континентальной окраины Монголо-Охотского океана // Геология и геофизика, 2012, т. 53, № 1, с. 30-49.

Забродин В.Ю., $\quad$ Гурьянов В.А., Кисляков С.Г., $\quad$ Кременецкая Н.А., Махинин А.В., Опалихина Е.С. Государственная геологическая карта Российской Федерации. Масштаб 1: 1000000. Серия Дальневосточная. Лист N-53. Третье поколение. С-Пб., ВСЕГЕИ, 2007.

Заика В.А., Сорокин А.А., Ковач В.П., Котов А.Б. Геохимия метаосадочных пород, источники кластического материала и тектоническая природа мезозойских впадин северного обрамления восточной части Монголо-Охотского складчатого пояса // Геология и геофизика, 2020, т. 61, № 3, с. 357-377.

Кадашникова А.Ю., Сорокин А.А., $\quad$ Пономарчук А.В., $\quad$ Травин А.В., Пономарчук В.А., Дементиенко А.И., Эйриш Л.В. ${ }^{40} \mathrm{Ar} /{ }^{39} \mathrm{Ar}$ возраст золотого оруденения месторождения Албын (восточная часть Монголо-Охотского складчатого пояса) // Доклады Академии наук, 2019а, т. 485, № 4, с. 468-473.

Кадашникова А.Ю., $\quad$ Сорокин А.А., $\quad$ Пономарчук А.В., $\quad$ Травин А.В., Пономарчук В.А., Дементиенко А.И., Эйриш Л.В. ${ }^{40} \mathrm{Ar} /{ }^{39} \mathrm{Ar} \quad$ возраст золоторудных метасоматитов месторождения Албын, Монголо-Охотский складчатый пояс // Тихоокеанская геология, 2019б, т. 38, № 6, с. 89-98.

Кадашникова А.Ю., Сорокин А.А., $\quad$ Пономарчук В.А., $\quad$ Травин А.В., Пономарчук А.В., Эйриш Л.В. Закономерности локализации оруденения, возраст и источники вещества золоторудного месторождения Маломыр (восточная часть МонголоОхотского складчатого пояса) // Геология рудных месторождений, 2019в, т. 61, № 1, с. 317.

Котов А.Б., Ларин А.М., Сальникова Е.Б., Великославинский С.Д., Глебовицкий В.А., Сорокин А.А., Яковлева С.3., Анисимова И.В. Раннемеловые коллизионные гранитоиды древнестанового комплекса Селенгино-Станового супертеррейна Центрально-Азиатского подвижного пояса // Доклады Академии наук, 2014, т. 456, № 4, с. 451-456. 
Котов А.Б., Мазукабзов А.М., Сковитина Т.М., Великославинский С.Д., Сорокин А.А., Сорокин А.П. Структурная эволюция и геодинамическая позиция Гонжинского блока (верхнее Приамурье) // Геотектоника, 2013, № 5, с. 351-361.

Лазарев А.Б., Волков А.В., Сидоров А.А. Рудовмещающие дуплексы золоторудного орогенного месторождения Маломыр (Приамурье) // Геология рудных месторождений, 2012, т. 54, № 6, с. 513-522.

Ларин А.М., Котов А.Б., Сальникова Е.Б., Сорокин А.А., Сорокин А.П., $\quad$ Яковлева С.3., Анисимова И.В. Гранитоиды тукурингрского комплекса Селенгино-Станового супертеррейна Центрально-Азиатского подвижного пояса: возраст и геодинамическая обстановка формирования // Доклады академии наук, 2014, т. 457, № 6, с. 692-697.

Ларин А.М., Котов А.Б., Сальникова Е.Б., Ковач В.П., Овчинникова Г.В., Саватенков В.М., Великославинский С.Д., Сорокин А.А., Васильева И.М., Сергеева Н.А., Мельников Н.Н., Ван К.Л., Чун С.Л. Гранитоиды позднестанового комплекса Джугджуро-Станового супертеррейна (Центрально-Азиатский складчатый пояс): возраст, тектоническое положение и источники // Петрология, 2018, т. 26, № 5, c. 463-485.

Ларин А.М., Сальникова Е.Б., К Котов А.Б., Глебовицкий В.А., Великославинский С.Д., Сорокин А.А., Яковлева С.3., Анисимова И.В. Раннемеловой возраст регионального метаморфизма становой серии Джугджуро-Становой складчатой области: геодинамические следствия // Доклады Академии наук, 2006, т. 409, № 2, с. 222-226.

Мельников А.В., Степанов В.А. Рудно-россыпные узлы Приамурской золотоносной провинции. Часть 2. Центральная часть провинции. Благовещенск, АмГУ, 2014, 300 с.

Натальин Б.А. Мезозойская аккреционная и коллизионная тектоника юга Дальнего Востока СССР // Тихоокеанская геология, 1991, № 5, с. 3-23.

Парфенов Л.М., Берзин Н.А., Ханчук А.И., Бадарч Г., Беличенко В.Г., Булгатов А.Н., $\quad$ Дриль С.И., $\quad$ Кириллова Г.Л., $\quad$ Кузьмин М.И., $\quad$ Ноклеберг У., Прокопьев А.В., Тимофеев В.Ф., Томуртогоо О., Янь Х. Модель формирования орогенных поясов Центральной и Северо-Восточной Азии // Тихоокеанская геология, 2003, т. 22, № 6, с. 7-41.

Парфенов Л.М., Попеко Л.И., Томуртогоо О. Проблемы тектоники МонголоОхотского орогенного пояса // Тихоокеанская геология, 1999, т. 18, № 5, с. 24-43.

Пономарчук В.А., Лебедев Ю.Н., Травин А.В., Морозова И.П., Киселева В.Ю., Титов А.Т. Применение тонкой магнитно-сепарационной технологии в $\mathrm{K}-\mathrm{Ar},{ }^{40} \mathrm{Ar}-{ }^{39} \mathrm{Ar}$, $\mathrm{Rb}-\mathrm{Sr}$ методах датирования пород и минералов // Геология и геофизика, 1998, т. 39 (1), c. 55-64.

Савчук Ю.С., Волков А.В. Крупные и суперкрупные орогенные золотые месторождения: геодинамика, структура, генетические следствия // Литосфера, 2019, т. 19, № 6, p. 813-833.

Сальникова Е.Б., Ларин А.М., Котов А.Б., Сорокин А.П., Сорокин А.А., Великославинский С.Д., Яковлева С.З., Федосеенко А.М., Плоткина Ю.В. ТокскоАлгоминский магматический комплекс Джугджуро-Становой складчатой области: возраст и геодинамическая обстановка формирования // Доклады академии наук, 2006, т. 409, № 5, с. $652-657$. 
Сережников А.Н., Волкова Ю.Р. Государственная геологическая карта Российской Федерации. Третье поколение. Дальневосточная серия. Масштаб 1: 000 000. Лист N-52, Зея / Под ред. Вольского А.С. Санкт-Петербург, ВСЕГЕИ, 2005.

Смирнова Ю.Н., Сорокин А.А., Попеко Л.И., Котов А.Б., Ковач В.П. Геохимия, источники и области сноса юрских терригенных отложений Верхнеамурского и ЗеяДепского прогибов восточной части Центрально-Азиатского складчатого пояса // Геохимия, 2017, № 2, с. 127-148.

Сорокин А.А., Кудряшов Н.М., Сорокин А.П., Рублев А.Г., Левченков О.А., Котов А.Б, Сальникова Е.Б., Ковач В.П. Геохронология, геохимия и геодинамическая позиция палеозойских гранитоидов восточного сегмента Монголо-Охотского складчатого пояса // Доклады Академии наук, 2003, т. 392, № 6, с. 807-812.

Сорокин А.А., Пономарчук А.В., Травин А.В., Пономарчук В.А., Вахтомин К.Д. ${ }^{40} \mathrm{Ar} /{ }^{39} \mathrm{Ar}$ возраст гранитоидов и связанного с ними золотого оруденения месторождения Кировское (юго-восточное обрамление Северо-Азиатского кратона) // Доклады академии наук, 2014а, т. 458, № 4, с. 452-458.

Сорокин А.А., Пономарчук В.А., Травин А.В., Рогулина Л.И., Пономарчук А.В. Корреляция процессов рудообразования на золото-полиметаллическом месторождении Березитовое западной части Селенгино-Станового супертеррейна и региональных тектоно-магматических событий // Геология и геофизика, 2014б, т. 55, № 3, с. 432-448.

Сотников В.И., Сорокин А.А., Пономарчук В.А., Гимон В.О., Сорокин А.П. Возраст Мо-Cu-(Au)-порфирового оруденения и магматических комплексов Боргуликанского рудного поля (Верхнее Приамурье) // Геология и геофизика, 2007а, т. 48, № 2, с. 229-237.

Сотников В.И., Сорокин А.А., Пономарчук В.А., Травин А.В., Сорокин А.П., Гимон В.О. Геохронология мезозойских гранитоидов и связанного с ними молибденового оруденения западной части Джугджуро-Станового супертеррейна // Доклады академии наук, 2007б, т. 416, № 6, с. 794-798.

Травин А.В., Юдин Д.С., Х Хромых С.В., Волкова Н.И., Мехоношин А.С., Владимиров А.Г., Колотилина Т.Б. Термохронология Чернорудской гранулитовой зоны (Ольхонский регион, Западное Прибайкалье) // Геохимия, 2009, т. 11, с. 1181-1199.

Ханчук А.И. Палеогеодинамический анализ формирования рудных месторождений Дальнего Востока России // Рудные месторождения континентальных окраин. Владивосток: Дальнаука, 2000, С. 5-34.

Эйриш Л.В. Металлогения золота Приамурья (Амурская область, Россия). Владивосток, Дальнаука, 2002, 194 с.

Baksi A.K., Archibald D.A., Farrar E. Intercalibration of ${ }^{40} \mathrm{Ar} /{ }^{39} \mathrm{Ar}$ dating standards // Chemical Geology, 1996, v. 129, p. 307-324.

Berger B.W., York D. Geothermometry from ${ }^{40} \mathrm{Ar} /{ }^{39} \mathrm{Ar}$ dating experiments // Geochimica et Cosmochimica Acta, 1981, v. 45, p. 795-811.

Demonterova E.I., Ivanov A.V., Mikheeva E.A., Arzhannikova A.V., Frolov A.O., Arzannikov S.G., Bryanskiy N.V., Pavlova L.A. Early to Middle Jurassic history of the southern Siberian continent (Transbaikalia) recorded in sediments of the Siberian Craton: Sm-Nd and U-Pb provenance study // Bulletin de la Société Géologique de France, 2017, v. 188 (1-2), p. 1-29.

Donskaya T.V., Gladkochub D.P., Mazukabzov A.M., Ivanov A.V. Late PaleozoicMesozoic subduction related magmatism at the southern margin of the Siberian continent and the 
150-million-year history of the Mongolia-Okhotsk ocean // Journal of Asian Earth Sciences, 2013, v. 62, p. 79-97.

Fleck R.J., Sutter J.F., Elliot D.H. Interpretation of discordant ${ }^{40} \mathrm{Ar} /{ }^{39} \mathrm{Ar}$ age spectra of Mesozoic tholeites from Antarctica // Geochimica et Cosmochimica Acta, 1977, v. 41, p. 15-32.

Goldfarb R.J., Groves D.I. Orogenic gold: Common or evolving fluid and metal sources through time // Lithos, 2015, v. 233, p. 2-26.

Groves D.I., Santosh M., Deng J., Wang Q., Yang L. Zhang L. A holistic model for the origin of orogenic gold deposits and its implications for exploration // Mineralium Deposita, 2020, v. 55, p. 275-292.

Gustafson L.B., Orquera W., McWilliams M., Castro M., Olivares O., Rojas G., Maluenda J., Mendez M. Multiple centers of mineralization in the Indio Muerto District, El Salvador, Chile // Economic Geology, 2001, v. 96, p. 325-350.

He Z.J., Li J.Y., Mo S.G., Sorokin A.A. Geochemical discriminations of sandstones from the Mohe Foreland basin, northeastern China: tectonic setting and provenance // Science in China Series D Earth Sciences, 2005, v. 48 (5), p. 613-621.

Kravchinsky V.A., Sorokin A.A., Courtillot V. Paleomagnetism of Paleozoic and Mesozoic sediments from the southern margin of Mongol-Okhotsk ocean, far eastern Russia // Journal of Geophysical Research Atmospheres, 2002, v. 107, p. 1-22.

Metelkin D.V., Gordienko I.V., Klimuk V.S. Paleomagnetism of Upper Jurassic basalts from Transbaikalia: new data on the time of closure of the Mongol-Okhotsk Ocean and Mesozoic intraplate tectonics of Central Asia // Russian Geology and Geophysics, 2007, v. 48 (10), p. 825-834.

Metelkin D.V., Gordienko I.V., Zhao Xixi. Paleomagnetism of Early Cretaceous volcanic rocks from Transbaikalia: argument for Mesozoic strike-slip motions in Central Asian structure // Russian Geology and Geophysics, 2004, v. 45 (12), p. 1349-1363.

Metelkin D.V., Vernikovsky V.A., Kazansky A.Yu., Wingate M.T.D. Late Mesozoic tectonics of Central Asia based on paleomagnetic evidence // Gondwana Research, 2010, v. 18, № 2-3, p. 400-419.

Natal'in B.A., Sengor A.M.C. Late Palaeozoic to Triassic evolution of the Turan and Scythian platforms: the pre-history of the palaeo-Tethyan closure // Tectonophysics, 2005, v. 404, p. 175-202.

Ren Q., Zhang S.H., Wu H.C., Liang Z.K., Miao X.J., Zhao H.Q., Li H.Y., Yang T.S., Pei J.L., Davis A.G. Further paleomagnetic results from the $\sim 155$ Ma Tiaojishan Formation, Yanshan Belt, North China, and their implications for the tectonic evolution of the MongolOkhotsk suture // Gondwana Research, 2016, v. 35, p. 180-191.

Sorokin A.A., Zaika V.A., Kovach V.P., Kotov A.B., Xu W. Timing of closure of the eastern Mongol-Okhotsk Ocean: constraints from U-Pb and Hf isotopic data of detrital zircons from metasediments along the Dzhagdy Transect // Gondwana Research, 2020, v. 81, p. 58-78.

Zhao X., Coe R.S., Zhou Y., Wu H., Kuang G., Dong Z., Wang J. Tertiary paleomagnetism of North and South China: a reappraisal of Late Mesozoic paleomagnetic data from Eurasia: Implications for the Cenozoic tectonic history of Asia // Tectonophysics, 1994, v. 235, p. 181-203. 


\section{ПОДПИСИ К РИСУНКАМ}

Рис. 1. Положение золоторудного месторождения Унгличикан в основных геологических структурах региона (по [Агафоненко и др., 2002] с изменениями авторов).

1-2 - стратифицированные геологические комплексы Селемджино-Кербинского террейна: 1 - мусковит-кварц-альбитовые, мусковит-альбит-кварцевые, альбит-хлоритэпидот-амфиболовые сланцы условно нижнепалеозойской афанасьевской свиты; 2 кварц-серицитовые, часто углеродсодержащие сланцы, эпидот-актинолит-альбитовые, кварц-эпидот-хлоритовые, хлорит-актинолит-кварц-альбитовые, мусковит-кварцальбитовые сланцы, метапесчаники, глинистые сланцы, метабазальты, мраморизованные известняки среднекаменноугольной златоустовской свиты; 3 - песчаники, алевролиты, известняки, метабазальты среднедевонской акриндинской свиты Галамского террейна; 4-5 - интрузии позднепалеозойского златоустовского комплекса: 4 - габбро, габбро-диориты, 5 - гранодиориты, плагиограниты; 6 - субвулканические тела раннемелового андезитриолитового унериканского комплекса; 7 - интрузии и субвулканические тела позднемелового диорит-гранодиорит-гранитового Баджало-Дуссе-Алиньского комплекса; 8 - дайки диоритовых порфиритов и андезитов первой фазы ранне-позднемелового селитканского комплекса, 9 - кайнозойские рыхлые отложения; 10 - разломы; 11 - контур врезки со схематической геологической картой центральной части золоторудного месторождения Унгличикан (по [Васильев и др., 2000] с изменениями авторов); 12 основные рудные зоны: Хабаровская (1), Шеелитовая (2), Милонитовая (3), Центральная (4), Брекчиевая (5), Дайковая (6), Дайковая-2 (7), Дальняя (8), Северная (9), Леоновская (10), Южная (11); 13 - проекции точек отбора образцов для геохронологических исследований и их номера; 14 - линия разреза А-Б (см. рис. 2). На врезке слева звездочкой показано положение золоторудного месторождения Унгличикан. Заштрихованная область - Монголо-Охотский складчатый пояс (МО). На врезке справа показана детальная карта центральной части золоторудного месторождения Унгличикан (по [Васильев и др., 2000] с изменениями авторов).

Рис. 2. Схематический геологический разрез месторождения Унгличикан по линии разреза А-Б, показанной на рисунке 1. Составлен по [Васильев и др., 2000] с упрощениями авторов.

Условные обозначения на рис. 1. Пунктиром показан контур карьера в 2015 г.

Рис. 3. Аргонограммы (ступенчатый прогрев) для минеральных фракций из гидротермальных рудных образований, вмещающих пород и дайки месторождения Унгличикан.

Номера образцов соответствуют номерам в тексте и таблицах.

Возраст приведен с погрешностью $\pm 2 \sigma$. 
Табл. 1. Содержание золота в образцах гидротермальных рудных образований, вмещающих пород и дайки месторождения Унгличикан.

\begin{tabular}{c|c|c}
\hline № образца & Порода & Аu, г/т \\
\hline АК-70 & адуляр-кварц-серицит-сульфидный метасоматит & 4.51 \\
АК-71-3 & адуляр-кварц-серицит-сульфидный метасоматит & 17.65 \\
АК-72-1 & углеродсодержащие кварц-полевошпат-слюдистые сланцы & 0.032 \\
АК-73 & андезит & 0.029 \\
\hline
\end{tabular}

Определения выполнены в Институте геологии и природопользования ДВО РАН атомноабсорбционным методом на спектрометре Solaar M6 + Zeeman Furnace (Thermo electron corporation, USA) с электротермической атомизацией (аналитики Н.А. Бородина, Е.Е. Зайцева, Н.Н. Козлова) 
Табл. 2. Результаты ${ }^{40} \mathrm{Ar} /{ }^{39} \mathrm{Ar}$ датирования минеральных фракций из гидротермальных рудных образований, вмещающих пород и дайки месторождения Унгличикан методом ступенчатого прогрева.

\begin{tabular}{|c|c|c|c|c|c|c|}
\hline $\begin{array}{c}\text { № } \\
\text { ступени }\end{array}$ & $\mathrm{T}^{\circ} \mathrm{C}$ & $\begin{array}{c}\sum^{39} \mathrm{Ar}, \\
\%\end{array}$ & ${ }^{40} \operatorname{Ar} /{ }^{39} \operatorname{Ar}( \pm 1 \sigma)$ & ${ }^{37} \operatorname{Ar} /{ }^{39} \operatorname{Ar}( \pm 1 \sigma)$ & ${ }^{36} \operatorname{Ar} /{ }^{39} \operatorname{Ar}( \pm 1 \sigma)$ & $\begin{array}{c}\text { Возраст. } \\
\text { млн. лет. }( \pm 1 \sigma)\end{array}$ \\
\hline \multicolumn{7}{|c|}{ Образец АК-70, адуляр, J=0.004004 \pm 0.000042} \\
\hline 1 & 500 & 0.8 & $260.24 \pm 41.83$ & $0.6 \pm 7.7$ & $0.9 \pm 0.2$ & $200.0 \pm 200.0$ \\
\hline 2 & 650 & 6.7 & $47.92 \pm 0.34$ & $4.3 \pm 1.0$ & $0.067 \pm 0.007$ & $192.2 \pm 12.8$ \\
\hline 3 & 750 & 20.2 & $29.23 \pm 0.11$ & $3.2 \pm 0.6$ & $0.051 \pm 0.002$ & $99.4 \pm 4.3$ \\
\hline 4 & 850 & 41.1 & $34.63 \pm 0.08$ & $14.4 \pm 0.8$ & $0.049 \pm 0.002$ & $139.4 \pm 4.8$ \\
\hline 5 & 950 & 59.4 & $26.78 \pm 0.07$ & $7.8 \pm 0.4$ & $0.018 \pm 0.002$ & $149.7 \pm 5.1$ \\
\hline 6 & 1050 & 75.8 & $24.99 \pm 0.07$ & $0.0 \pm 0.1$ & $0.016 \pm 0.002$ & $141.5 \pm 5.0$ \\
\hline 7 & 1130 & 100.0 & $23.10 \pm 0.06$ & $0.5 \pm 0.2$ & $0.012 \pm 0.001$ & $136.9 \pm 2.8$ \\
\hline \multicolumn{7}{|c|}{ 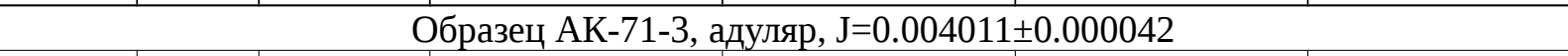 } \\
\hline 1 & 600 & 6.6 & $173.2 \pm 1.9$ & $3.2 \pm 2.2$ & $0.16 \pm 0.01$ & $739.1 \pm 17.5$ \\
\hline 2 & 750 & 23.4 & $66.77 \pm 0.67$ & $13.0 \pm 0.7$ & $0.096 \pm 0.010$ & $258.6 \pm 18.7$ \\
\hline 3 & 825 & 36.0 & $75.76 \pm 0.61$ & $43.8 \pm 1.3$ & $0.193 \pm 0.007$ & $131.2 \pm 14.0$ \\
\hline 4 & 900 & 56.2 & $30.34 \pm 0.18$ & $0.5 \pm 0.4$ & $0.035 \pm 0.006$ & $139.6 \pm 11.0$ \\
\hline 5 & 1025 & 100.0 & $24.19 \pm 0.03$ & $0.6 \pm 0.2$ & $0.0156 \pm 0.0007$ & $136.4 \pm 2.0$ \\
\hline \multicolumn{7}{|c|}{ Образец АК-72-1, серицит, J=0.005468 \pm 0.000076} \\
\hline 1 & 500 & 1.0 & $47.7 \pm 0.3$ & $0.17 \pm 0.09$ & $0.141 \pm 0.007$ & $59.6 \pm 19.2$ \\
\hline 2 & 625 & 6.5 & $28.18 \pm 0.07$ & $0.37 \pm 0.03$ & $0.060 \pm 0.002$ & $100.4 \pm 5.9$ \\
\hline 3 & 700 & 16.8 & $19.87 \pm 0.01$ & $0.24 \pm 0.02$ & $0.0181 \pm 0.0004$ & $137.8 \pm 2.2$ \\
\hline 4 & 775 & 28.8 & $18.42 \pm 0.03$ & $0.031 \pm 0.008$ & $0.0116 \pm 0.0008$ & $142.1 \pm 2.9$ \\
\hline 5 & 850 & 57.5 & $16.86 \pm 0.02$ & $0.016 \pm 0.005$ & $0.0068 \pm 0.0009$ & $140.9 \pm 3.1$ \\
\hline 6 & 900 & 68.8 & $17.44 \pm 0.03$ & $0.012 \pm 0.009$ & $0.010 \pm 0.002$ & $137.2 \pm 4.9$ \\
\hline 7 & 975 & 85.0 & $16.77 \pm 0.01$ & $0.02 \pm 0.01$ & $0.0064 \pm 0.0005$ & $141.1 \pm 2.3$ \\
\hline 8 & 1025 & 95.6 & $17.59 \pm 0.02$ & $0.01 \pm 0.01$ & $0.014 \pm 0.001$ & $128.5 \pm 3.5$ \\
\hline 9 & 1080 & 100.0 & $24.36 \pm 0.03$ & $0.15 \pm 0.01$ & $0.034 \pm 0.001$ & $137.1 \pm 3.8$ \\
\hline \multicolumn{7}{|c|}{ 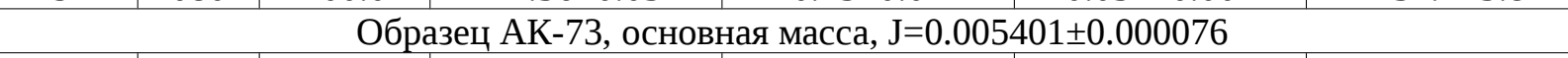 } \\
\hline 1 & 500 & 3.2 & $5.9 \pm 0.8$ & $2.2 \pm 0.2$ & $0.28 \pm 0.07$ & $-948.6 \pm 344.5$ \\
\hline 2 & 850 & 31.1 & $13.75 \pm 0.02$ & $0.18 \pm 0.01$ & $0.012 \pm 0.001$ & $97.4 \pm 3.8$ \\
\hline 3 & 925 & 57.6 & $13.11 \pm 0.02$ & $0.14 \pm 0.01$ & $0.010 \pm 0.002$ & $95.4 \pm 4.6$ \\
\hline 4 & 1030 & 71.9 & $15.64 \pm 0.04$ & $0.05 \pm 0.02$ & $0.016 \pm 0.002$ & $103.8 \pm 6.7$ \\
\hline 5 & 1130 & 100.0 & $13.34 \pm 0.03$ & $0.07 \pm 0.01$ & $0.011 \pm 0.001$ & $96.8 \pm 4.1$ \\
\hline
\end{tabular}

Примечание. Т - температура, погрешность $\pm 1{ }^{\circ} \mathrm{C} . \mathrm{J}$ - «джей-фактор» - параметр, характеризующий нейтронный поток. 


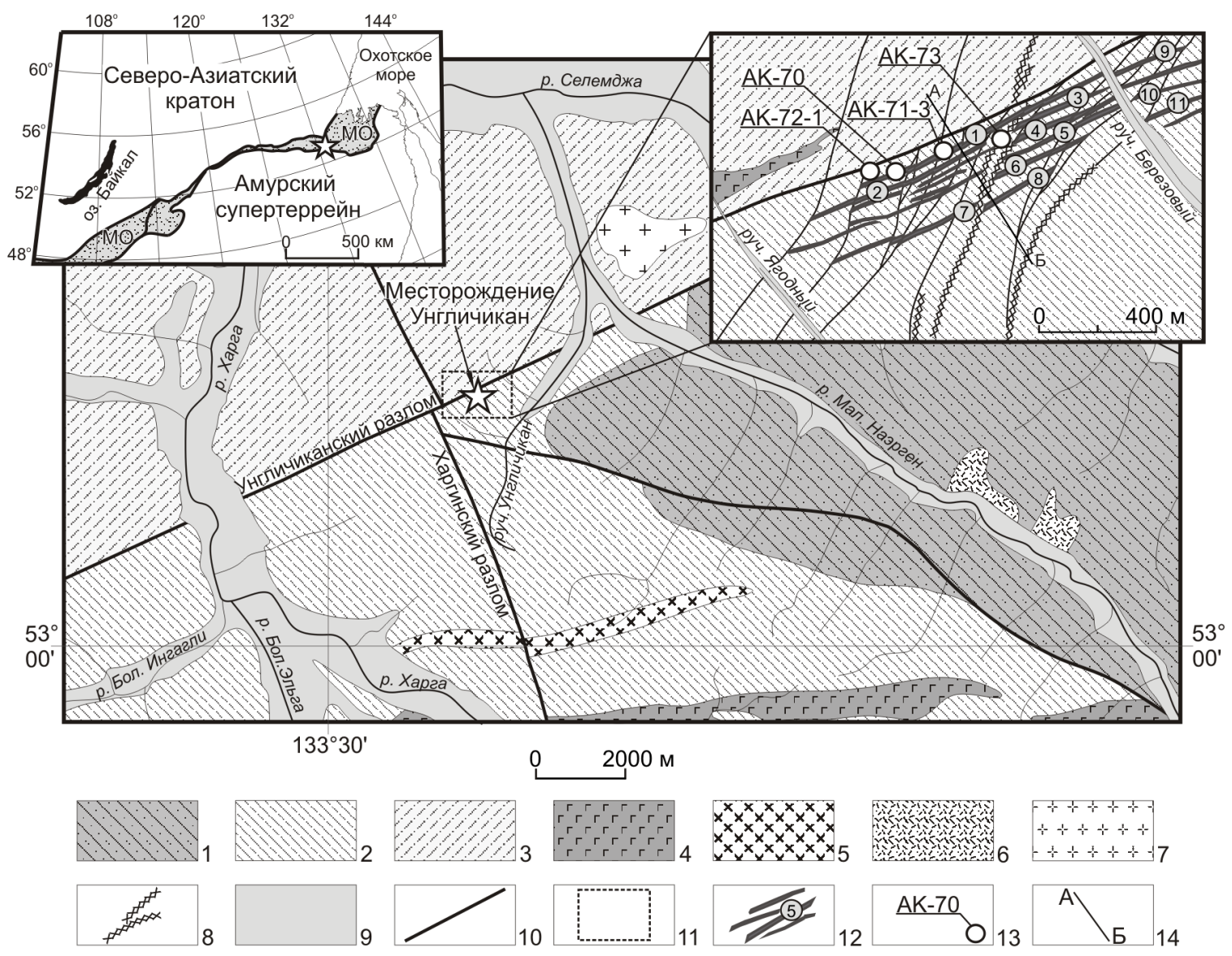

Рис. 1 к статье А.Ю. Кадашниковой и др. "Возраст золотого оруденения месторождения Унгличикан...” 


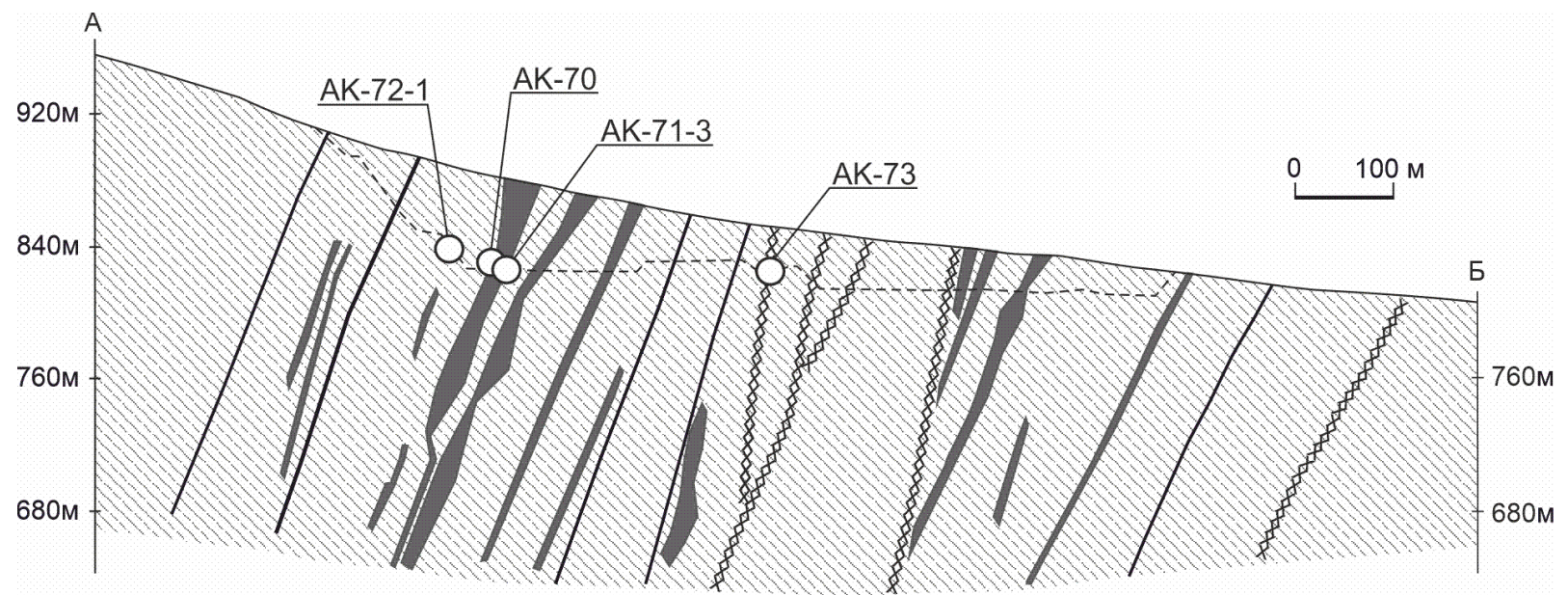

Рис. 2 к статье А.Ю. Кадашниковой и др. “Возраст золотого оруденения месторождения Унгличикан...” 

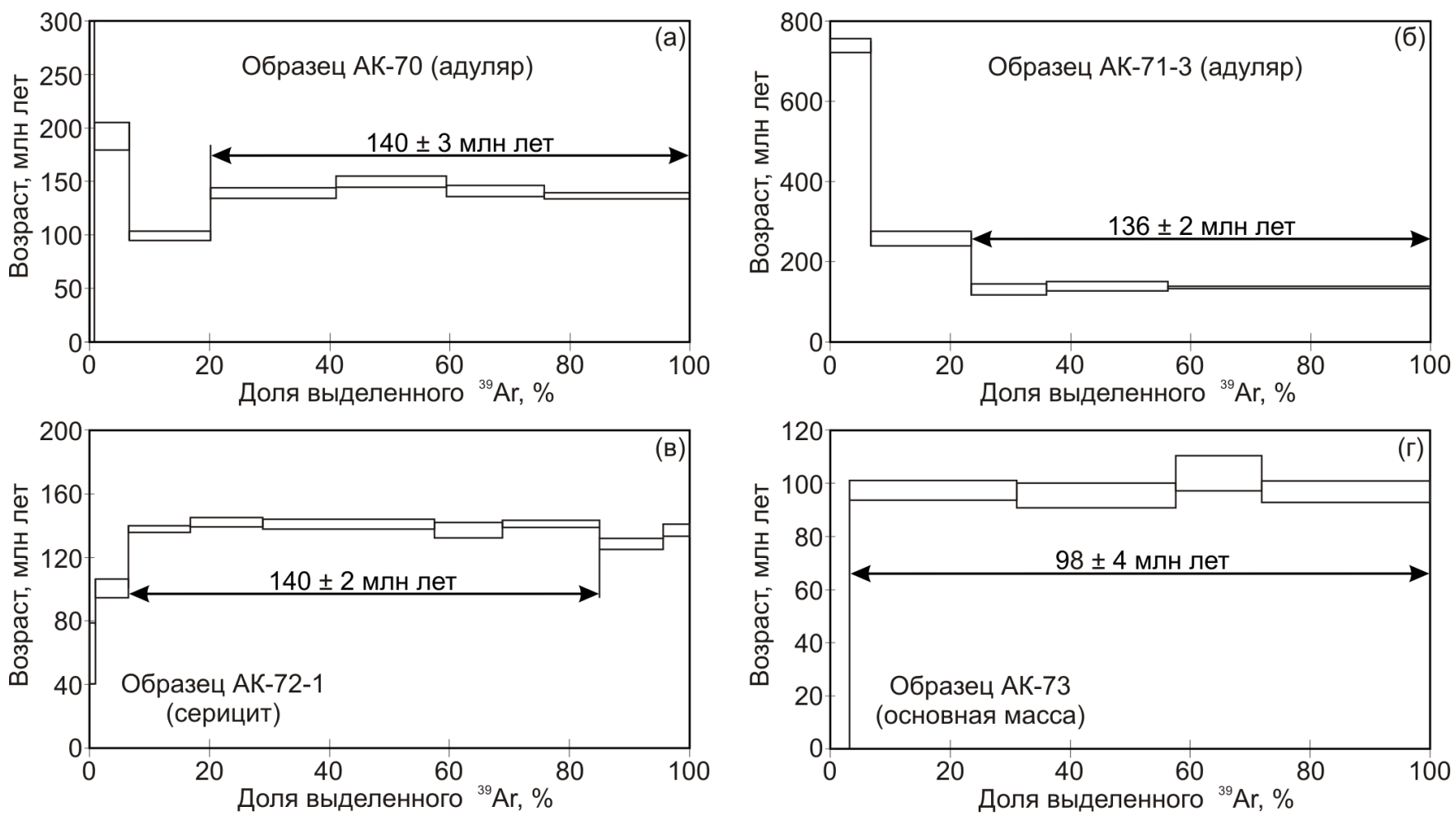

Рис. 3 к статье А.Ю. Кадашниковой и др. “Возраст золотого оруденения месторождения Унгличикан...” 